\title{
Unsuccessful intravenous D-mannose treatment in PMM2-CDG
}

\author{
Sarah C. Grünert ${ }^{1 *}$ D, Thorsten Marquardt ${ }^{2}$, Ekkehart Lausch ${ }^{1}$, Hans Fuchs ${ }^{1}$, Christian Thiel ${ }^{3}$, Martin Sutter ${ }^{4}$, \\ Anke Schumann ${ }^{1}$, Luciana Hannibal ${ }^{5}$ and Ute Spiekerkoetter ${ }^{1}$
}

\begin{abstract}
Background: PMM2-CDG (Phosphomannomutase 2 - Congenital disorder of glycosylation-la; CDG-la) is the most common glycosylation defect, often presenting as a severe multisystem disorder that can be fatal within the first years of life. While mannose treatment has been shown to correct glycosylation in vitro and in vivo in mice, no convincing effects have been observed in short-term treatment trials in single patients so far.
\end{abstract}

Results: We report on a boy with a severe PMM2-CDG who received a continuous intravenous mannose infusion over a period of 5 months during the first year of life in a dose of $0.8 \mathrm{~g} / \mathrm{kg} /$ day. N-glycosylation of serum glycoproteins and mannose concentrations in serum were studied regularly. Unfortunately, no biochemical or clinical improvement was observed, and the therapy was terminated at age 9 months.

Conclusion: Postnatal intravenous D-mannose treatment seems to be ineffective in PMM2-CDG.

Keywords: PMM2-CDG, Congenital disorder of glycosylation, Mannose

\section{Background}

PMM2-CDG is usually a severe multisystem disorder caused by mutations in the gene that encodes phosphomannomutase 2 (MIM 212065) [1]. This enzyme catalyzes the cytosolic conversion of mannose-6-phosphate to mannose-1-phosphate, thereby generating a key substrate for $\mathrm{N}$-glycan biosynthesis. Deficiency of PMM2 enzymatic activity causes $\mathrm{N}$-linked hypoglycosylation of serum and cellular proteins [2] and marked reduction of total serum mannose compared to controls [3]. The phenotype is broad and comprises hypotonia, developmental delay, failure to thrive, cerebellar atrophy, pericardial effusion, seizures, coagulopathy, hepatopathy, gastrointestinal symptoms, hypothyroidism, esotropia, osteopenia and abnormal subcutaneous fat patterns [1, 3-6]. Severe forms are often fatal within the first years of life. There is currently no cure or approved treatment for PMM2-CDG [2].

Studies in fibroblasts of patients with PMM2-CDG have shown that the incorporation of labelled mannose

\footnotetext{
* Correspondence: Sarah.gruenert@uniklinik-freiburg.de

${ }^{1}$ Department of General Pediatrics, Adolescent Medicine and Neonatology, Faculty of Medicine, Medical Center - University of Freiburg, Mathildenstraße 1, 79106 Freiburg, Germany

Full list of author information is available at the end of the article
}

into proteins was significantly reduced and that the size of the lipid-linked oligosaccharide precursor (LLO) was smaller than in controls. Addition of exogenous mannose to the culture medium in a concentration of $250 \mu \mathrm{mol} / \mathrm{L}$ or higher corrected the hypoglycosylation phenotype in fibroblasts [4]. This correction was transient, since biochemical abnormalities reappeared when mannose was removed. This has been replicated in other in vitro $[3,5,6]$ and in vivo models [2, 7]. In two different hypomorphic PMM2-CDG mouse models, feeding mannose to pregnant dams reduced [2] or even prevented embryonic lethality [7], demonstrating for the first time a biological effect of mannose in vivo. Short-term oral mannose treatment of PMM2-CDG patients has failed to correct glycosylation [8-11].

Intravenous mannose therapy was previously applied in one 11-month old PMM2-CDG patient [10]. Continuous intravenous mannose led to a unique change of the isoelectrofocusing pattern of serum sialotransferrins with appearance of two extra bands after 3 weeks of treatment. Mannose treatment had no clinical effect during this short study period.

We report biochemical and clinical findings in a boy with PMM2-CDG who received continuous intravenous mannose treatment for 5 months. 


\section{Methods}

D-mannose (Euro OTC Pharma) for intravenous administration was obtained as a sterile filtrated (Millex GP 0, $22 \mu \mathrm{m}$ ) and non-pyrogenic (proved by LAL-test) $10 \%$ solution (wt/vol) in water for injections. This mannose solution was administered continuously through a central vein catheter for a period of 5 months. The dose was slowly increased from $0.1 \mathrm{~g} / \mathrm{kg} /$ day to a final dosage of $0.8 \mathrm{~g} / \mathrm{kg} /$ day within 9 days. Compassionate use of this intravenous trial was approved by an interdisciplinary ethics board meeting (June 2018, including geneticists, metabolic physicians, intensive care physicians and neuropediatricians). Written informed consent for this treatment was obtained from both parents in accordance with rules and regulations for critically ill patients treated at Freiburg University Hospital (06.06.2019). Biochemical response to treatment was initially evaluated weekly for the first 2 months, later once a month. Serum mannose concentrations were analysed by GC/MS. Nglycosylation of serum glycoproteins (transferrin and alpha1-antitrypsin) was studied by isoelectric focusing (IEF) and HPLC as described [12]. Assessment of the clinical response comprised daily physical examinations as well as regular echocardiography and electroencephalography.

\section{Case report and results}

The boy is the second child of non-consanguineous Caucasian parents. Birth and perinatal period were unremarkable. At the age of 6 weeks he was admitted to the hospital due to vomiting and diarrhea. He was tachycardic (heart rate $160 / \mathrm{min}$ ), and a systolic murmur was noted. Echocardiography revealed pericardial effusion, and the child was transferred to our university hospital in poor clinical condition. Additional clinical findings comprised hepatomegaly, inverted nipples, bilateral cryptorchidism and inguinal hernias, muscular hypotonia and an abnormal subcutaneous fat pattern (Fig. 1a-c). Initial laboratory abnormalities included leucocytosis $(26.3 \mathrm{G} / \mathrm{L})$, thrombocytosis (720 G/ $\mathrm{L}$ ), anemia ( $\mathrm{Hb} 11.1 \mathrm{~g} / \mathrm{dl})$, impaired coagulation parameters (INR 1.19, normal 0.85-1.15; antithrombin III $28 \%$, normal $80-130 \%)$, hypomagnesemia $(0.53 \mathrm{mmol} /$ $\mathrm{L}$, normal $0.7-0.95 \mathrm{mmol} / \mathrm{L})$, elevated transaminases (ASAT $67 \mathrm{U} / \mathrm{L}$; ALAT $65 \mathrm{U} / \mathrm{L}$, normal 10-50 U/L, respectively), low haptoglobin $(10 \mathrm{mg} / \mathrm{dL}$, normal $30-$ $200 \mathrm{mg} / \mathrm{dL}$ ), severe hypoproteinemia (total protein 2.0 $\mathrm{g} / \mathrm{dL}$, normal $5.1-7.3 \mathrm{~g} / \mathrm{dL}$; albumin $1.2 \mathrm{~g} / \mathrm{dL}$, normal $3.8-5.4 \mathrm{~g} / \mathrm{dL}$ ), proteinuria (protein in spot urine 210 $\mathrm{mg} / \mathrm{dL}$, normal < $15 \mathrm{mg} / \mathrm{dL}$; protein/creatinine ratio $3.14 \mathrm{mg} / \mathrm{mg}$, normal $<0.2 \mathrm{mg} / \mathrm{mg}$; albumin in spot urine $171 \mathrm{mg} / \mathrm{L}$, normal < $30 \mathrm{mg} / \mathrm{L}$; albumin/creatinine ratio $255.6 \mathrm{mg} / \mathrm{g}$ creatinine, normal $<16.2 \mathrm{mg} / \mathrm{g}$ creatinine) and hypothyroidism (TSH $28.1 \mu \mathrm{U} / \mathrm{mL}$, normal $0.73-8.35 \mu \mathrm{U} / \mathrm{mL}$; free T4 $10.9 \mathrm{pmol} / \mathrm{L}$, normal 11.9-25.6 pmol/L).
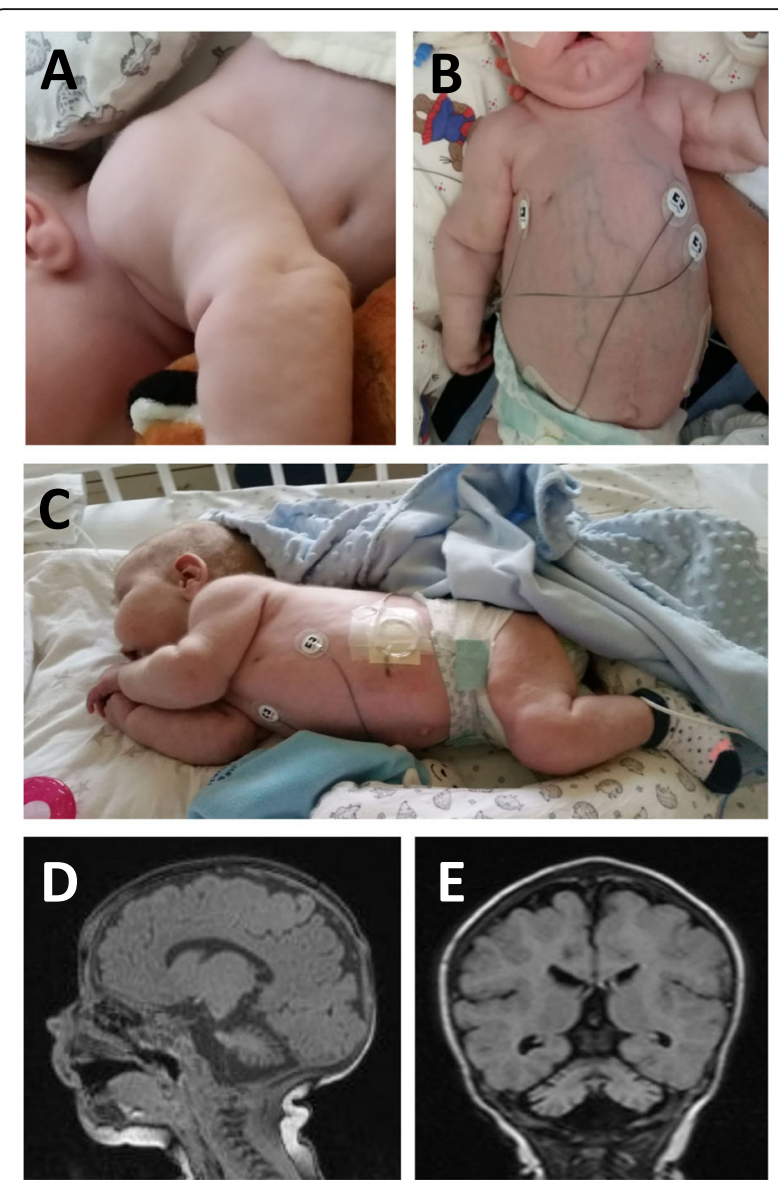

Fig. 1 Characteristic clinical findings of PMM2-CDG. a-c Inverted nipples, abnormal subcutaneous fat distribution, ascites. d-e Brain $\mathrm{MRI}$ of the patient at age 2.5 months showing cerebellar atrophy

Diagnostic work-up revealed serum transferrin and alpha-1-antitrypsin isoelectrofocusing patterns suggestive of CDG-I. PMM2 activity in cultured fibroblasts was markedly reduced $(0.1 \mathrm{mU} / \mathrm{mg}$, reference range $1.0-1.5 \mathrm{mU} /$ $\mathrm{mg}$ ), which associates with moderate phenotypes of the disease [13]. Mutation analysis of the PMM2 gene yielded compound-heterozygosity for the variants c.422G $>$ A (p.Arg141His) and c.691G > A (p.Val231Met). The mother was heterozygous for the c.691G >A variant, while the father carried the c. $422 \mathrm{G}>\mathrm{A}$ variant. Both sequence changes were reported as pathogenic [14] and impair enzymatic activity [15]. The most common variant p.Arg141His disrupts substrate binding and catalysis [16] and leads to PMM2 proteins with nearly undetectable enzymatic activity [14]. In contrast, variant p.Val231Met retains measurable residual activity in vitro [15] but it is thermally unstable [16]. Mutation of Arg141 to His increases the Km of the PMM2 for substrate D-mannose by one order of magnitude [16].

The pericardial effusion was not hemodynamically relevant, but the patient developed hypertrophic cardiomyopathy 
with obstruction of the left ventricular outflow tract and was treated with metoprolol. Parenteral nutrition was necessary due to fulminant diarrhea with high protein loss. He also developed ascites requiring permanent drainage and substitution of albumin and antithrombin III. Protein $\mathrm{C}$ was severely reduced and substituted as well as fresh frozen plasma. He received erythrocyte and thrombocyte transfusions due to persistent anemia and thrombocytopenia. Brain MRI at the age of 2.5 months showed cerebellar atrophy (Fig. 1d, e), characteristic for PMM2-CDG. At the age of 3 months he developed generalised tonic-clonic seizures that were treated with phenobarbital. The EEG showed a focal epileptic activity over the left parietal hemisphere. Other neurological abnormalities included horizontal nystagmus and esotropia. L-Thyroxin treatment was initiated due to hypothyroidism.

At the age of 4 months an intravenous D-mannose trial was started. D-mannose was continuously infused with a starting dose of $0.1 \mathrm{~g} / \mathrm{kg} / \mathrm{d}$. Over the next 9 days the dose was progressively increased to $0.8 \mathrm{~g} / \mathrm{kg}$ D-mannose per day. No side effects occurred under this treatment. Analyses of transferrin glycosylation and of serum D-mannose concentrations were performed regularly. The results are shown in Fig. 2. Mannose concentrations in serum before therapy were below $50 \mu \mathrm{mol} / \mathrm{L}(n=2)$. During therapy, mannose concentrations were between 111.2 and $146.7 \mu \mathrm{mol} / \mathrm{L}(n=4$, mean $128.7 \mu \mathrm{mol} / \mathrm{L})$ with one higher value $(236.3 \mu \mathrm{mol} / \mathrm{L})$. No major improvement of glycosylation was observed during the 5-month study period. Due to the lack of biochemical and clinical improvement, mannose therapy was terminated at age 9 months. In sum, none of the symptoms (cardiomyopathy, diarrhea and ascites, neurological symptoms) changed significantly during the mannose trial.

At the age of 10 months the patient was dismissed from hospital. His body weight was $9 \mathrm{~kg}$ (97th centile), his length $70 \mathrm{~cm}$ (7th centile) and his head circumference $44.5 \mathrm{~cm}$ (7th centile). During the follow-up he was admitted for albumin infusions and laboratory monitoring once a week. Two short inpatient treatments were necessary due to febrile infections. During one of these episodes Acinetobacter braumanii was detected in the ascites and was treated with meropenem.

As the boy had survived several febrile episodes without significant clinical deterioration, the risk of a mild febrile vaccination reaction was considered lower than the risk of severe infections without vaccination despite the known thermolability of the p.Val231Met variant.

At the age of 11 months he was admitted for his regular albumin infusion in good clinical condition. On the same day he received a routine vaccination. On the following day, he was sub-febrile and required oxygen. Few hours later the respiratory situation worsened rapidly, he became tachypnoeic and developed a global respiratory insufficiency. Mechanical ventilation was started and he required up to $100 \%$ oxygen. Echocardiography confirmed the pre-existing pericardial effusion and cardiomyopathy, without further deterioration. One day later

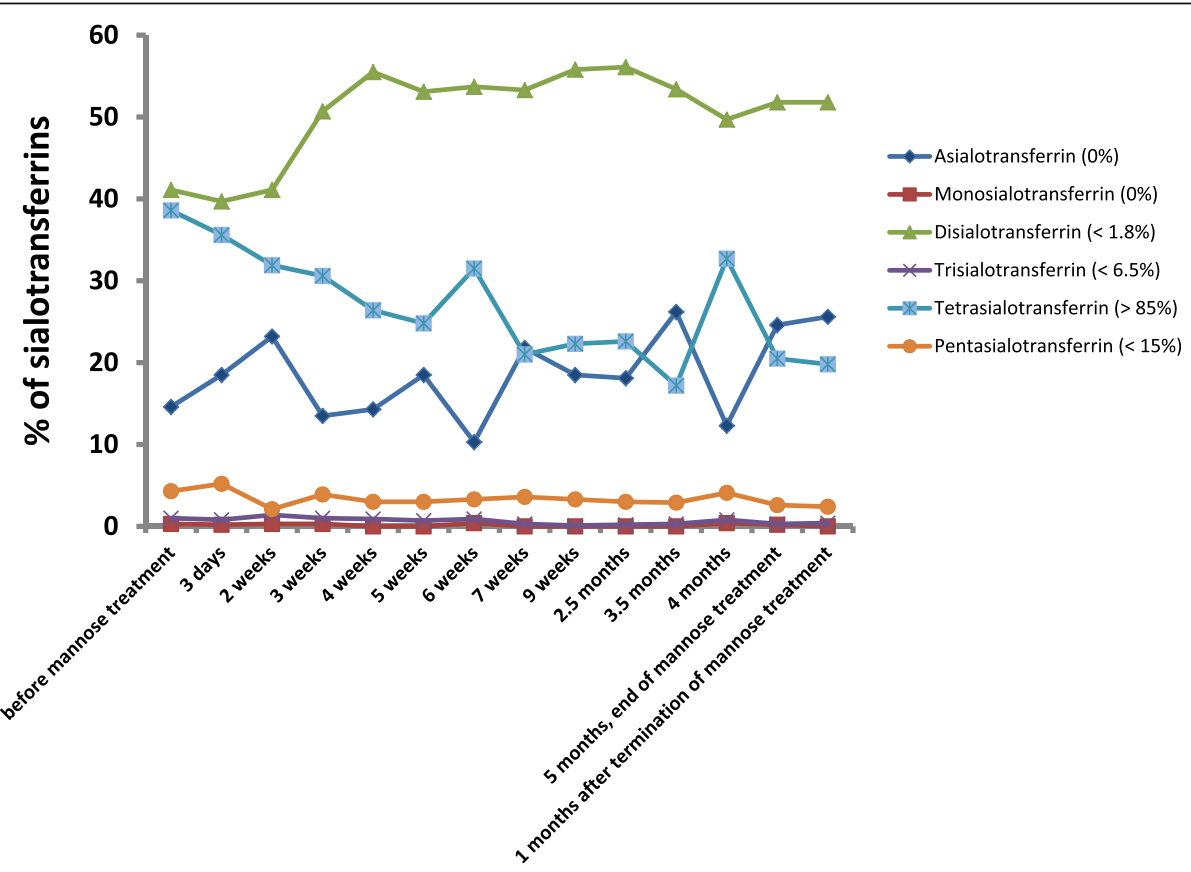

Fig. 2 Sialotransferrin pattern of the patient before intravenous mannose therapy, during the treatment trial and after termination of mannose therapy. No relevant change/normalisation of the sialotransferrin pattern could be observed under mannose treatment 
the blood pressure suddenly dropped (syst. Pressure 20 $\mathrm{mmHg}$ ) and severe arrhythmias occurred, leading to fatal cardiac failure. No autopsy was performed.

\section{Discussion}

This study aimed to investigate the clinical outcome of a PMM2-CDG boy upon continuous intravenous mannose infusion administered over a period of 5 months within his first year of life (dose of $0.8 \mathrm{~g} / \mathrm{kg} /$ day). To our knowledge, this is the first study performing a long-term continuous infusion mannose intervention in a severely affected PMM2-CDG infant.

Reports dating back to over two decades described promising effects of mannose administration on PMM2deficient fibroblasts in vitro [4]. Since then, only a few studies were performed in humans using either enteral (5 patients) or parenteral (1 patient) D-mannose supplementation [8-10]. No clinical or biochemical improvement was observed in any of these short-term treatment studies [8-10]. Because in these trials mannose was only administered for a period of a few weeks, we hypothesized that a longer trial may be helpful to achieve the desired therapeutic effects. Results of long-term studies were not yet available.

Our patient presented with a severe, early diagnosed PMM2-CDG. Mannose treatment was mainly considered due to the lack of other therapeutical options and a poor clinical condition. Although mannose is usually well absorbed and oral administration increases mannose blood levels [17], this therapeutic approach was not possible in our patient due to severe diarrhea and ascites. We could neither observe a clinical nor a biochemical response (including serum transferrin IEF) to Dmannose.

Therapeutic development for patients with PMM2CDG has suffered from substantial paucity. Table 1 summarizes animal and human studies on the few reported PMM2-CDG treatments. Schneider et al. reported successful prenatal treatment with mannose in a hypomorphic PMM2-CDG mouse model [7]. Embryonic lethality was prevented by feeding mannose to pregnant dams, underlining the essential role of glycosylation in embryonic development [7]. The authors hypothesized that one reason for the unresponsiveness to D-mannose treatment in infancy might be the fact that essential

Table 1 Studies on therapy and PMM2-CDG disease modeling with intervention

\begin{tabular}{|c|c|c|c|c|}
\hline Description & Subject & Mutation & Outcome & Reference \\
\hline $\begin{array}{l}\text { Continuous infusion of D-mannose }(0.8 \mathrm{~g} / \mathrm{kg} / \text { day }) \text {, for } \\
5 \text { months during the first year of life }\end{array}$ & Human & $\begin{array}{l}\text { c.422G > A (p.Arg141His) and } \\
\text { c.691G > A (p.Val231Met). }\end{array}$ & Unsuccessful & This study \\
\hline $\begin{array}{l}\text { Oral acetazolamide dosages from } 6.8 \text { to } 16.7 \text { mg/kg per } \\
\text { day were well tolerated. Treatment lasted 6-months, } \\
\text { followed by a randomized 5-week withdrawal phase. }\end{array}$ & Human & $\begin{array}{l}24 \text { subjects with various } \\
\text { mutations }\end{array}$ & $\begin{array}{l}\text { Clinical improvement of } \\
\text { cerebellar syndrome }\end{array}$ & $\begin{array}{l}\text { Ann Neurol. 2019; } \\
\text { 85:740-51. }\end{array}$ \\
\hline $\begin{array}{l}\text { Five children with PMM2-CDG, received enteral } \\
\text { supplementation with d-mannose } 100 \mathrm{mg} / \mathrm{kg} \text { every } \\
3 \mathrm{~h} \text { for } 9 \mathrm{~d} \text {. }\end{array}$ & Humans & $\begin{array}{l}\text { F119L/R141H } \\
\text { R141H/unknown }\end{array}$ & Unsuccessful & $\begin{array}{l}\text { Acta Paediatr. } \\
\text { 1998;87:884-8. }\end{array}$ \\
\hline $\begin{array}{l}\text { Continuous infusion of mannose } 5.7 \mathrm{~g} / \mathrm{kg} / \text { day, for } \\
3 \text { weeks, within first year of life. Stable serum mannose } \\
\text { levels up to } 2.0 \mathrm{mmol} / \mathrm{L} \text { were maintained. No signs of } \\
\text { liver or renal toxicity. }\end{array}$ & Humans & Not reported & Unsuccessful & $\begin{array}{l}\text { Acta Paediatr. } \\
\text { 1997;86:1138-40. }\end{array}$ \\
\hline $\begin{array}{l}\text { Oral doses of } 0.17 \mathrm{~g} \\
(1.0 \mathrm{mmol}) \text { mannose/kg body weight every } 3.5 \mathrm{~h} \text {, for } \\
6 \text { months. Patient was } 12 \text { months old at start of treatment. }\end{array}$ & Human & Phe119Leu/ Arg141His & Unsuccessful & $\begin{array}{l}\text { Eur J Pediatr. 1998; } \\
\text { 157:605-6. }\end{array}$ \\
\hline $\begin{array}{l}\text { Cultured fibroblasts, } 0.25 \mathrm{mmol} / \mathrm{L} \text { D-mannose added to } \\
\text { the culture medium }\end{array}$ & $\begin{array}{l}\text { Human } \\
\text { fibroblasts }\end{array}$ & Not reported & $\begin{array}{l}\mathrm{N} \text {-linked glycosylation } \\
\text { restored to normal }\end{array}$ & $\begin{array}{l}\text { J Clin Invest. 1996; } \\
\text { 97:1478-87. }\end{array}$ \\
\hline $\begin{array}{l}\text { Cultured fibroblasts, } 1 \mathrm{mmol} / \mathrm{L} \text { D-mannose added to } \\
\text { the culture medium }\end{array}$ & $\begin{array}{l}\text { Human } \\
\text { fibroblasts }\end{array}$ & Not reported & $\begin{array}{l}\text { Recovery of GDP- } \\
\text { Mannose pools }\end{array}$ & $\begin{array}{l}\text { Glycobiology. } \\
\text { 2000;10:829-35. }\end{array}$ \\
\hline $\begin{array}{l}\text { Cultured fibroblasts, } 1 \mathrm{mmol} / \mathrm{L} \text { D-mannose added to } \\
\text { the culture medium } \\
\text { In addition, glucose reduction from } 5 \mathrm{mmol} / \mathrm{L} \text { to } \\
0.5 \mathrm{mmol} / \mathrm{L} \text { improved D-mannose uptake and restoral of } \\
\mathrm{N} \text {-glycosylation }\end{array}$ & $\begin{array}{l}\text { Human } \\
\text { fibroblasts }\end{array}$ & Not reported & $\begin{array}{l}\mathrm{N} \text {-linked glycosylation } \\
\text { restored to normal }\end{array}$ & $\begin{array}{l}\text { Glycoconj J. 1998; } \\
\text { 15:499-505. }\end{array}$ \\
\hline $\begin{array}{l}\text { Cultured fibroblasts, } 0.25 \mathrm{mmol} / \mathrm{L} \text { D-mannose added to } \\
\text { the culture medium }\end{array}$ & $\begin{array}{l}\text { Human } \\
\text { fibroblasts }\end{array}$ & Not reported & $\begin{array}{l}\mathrm{N} \text {-linked glycosylation } \\
\text { restored to normal }\end{array}$ & $\begin{array}{l}\text { Biochem Mol Med. } \\
\text { 1997;61:161-7. }\end{array}$ \\
\hline $\begin{array}{l}\text { Treatment of female mice with } 9 \mathrm{mg} \\
\text { mannose per } \mathrm{mL} \text { drinking water, } 1 \text { week before mating }\end{array}$ & Mice & Pmm2 R137H/F118 L embryos & Successful & $\begin{array}{l}\text { Nat Med. 2011;18: } \\
\text { 71-3. }\end{array}$ \\
\hline $\begin{array}{l}\text { Treatment of female mice with } 9 \text { mg } \\
\text { mannose per } \mathrm{mL} \text { drinking water, } 1 \text { week before mating }\end{array}$ & Mice & Pmm2 F115 L embryos & Successful & $\begin{array}{l}\text { Hum Mol Genet. } \\
\text { 2016;25:2182-93. }\end{array}$ \\
\hline
\end{tabular}


developmental steps during embryogenesis and infancy may have already been irreversibly affected by hypoglycosylation [7].

In accordance with earlier reports, we did not observe any side effects from the high doses of intravenous Dmannose in our patient. In the only other PMM2 patient treated with D-mannose intravenously [10], a dose of up to $5.7 \mathrm{~g} / \mathrm{kg} /$ day, led to stable serum mannose levels up to $2.0 \mathrm{mmol} / \mathrm{l}$. We administered a significantly lower dose than that reported by Mayatepek et al. such in order to diminish the chance of potential side effects. This led to serum concentrations that remained below the threshold known to correct glycosylation of cultured fibroblasts (see Table 1).

Our patient showed a very rapid clinical deterioration and died shortly after a routine vaccination with a mild febrile reaction. Taking into consideration that the patient carried one null mutation and the sequence variant p.Val231Met known to result in a thermolabile PMM2 protein, it is plausible that the post-vaccination fever was responsible for acute worsening of glycosylation with fatal outcome.

\section{Conclusion}

In conclusion, treatment with intravenous D-mannose over a period of 5 months neither led to a biochemical nor to a clinical response in our patient. Possible reasons for the negative outcome in our patient include: (i) The period of treatment was too short, (ii) Higher doses of mannose may be necessary, (iii) The variant combination in our patient that disrupts both substrate binding and catalysis, as well as protein stability, may be biochemically difficult to correct, even if an adequate concentration of D-mannose does reach the active site of the mutated enzyme.

\section{Ongoing developments and future outlook in PMM2-CDG therapy}

Treatment success may largely depend on a patient's individual ability to stabilize abnormal PMM2 via cellular chaperones such as has been proposed for Hsp90 [18-20] Along these lines, in silico studies support the exploration of pharmacological chaperones for the stabilization of unstable variants of PMM2 [21]. Two independent studies with mice showed a marked improvement of the embryological lethality of PMM2 hypomorphs upon treatment of mothers with mannose prior to mating, potentially via mechanisms other than rescue of PMM2 enzymatic activity, such as differential gene programming [7].

Development of stem cells of PMM2-CDG patients exhibiting gradual reduction of $\mathrm{N}$-glycosylation will permit the study of PMM2 deficiency at the cellular and molecular levels [22]. In terms of therapeutic strategies, alternative methods have been developed to facilitate the uptake and incorporation of mannose, such as the synthesis of membrane permeable, hydrophobic mannose-1-phosphate-based prodrugs [23, 24]. These hydrophobic mannose-1-phosphate compounds were shown to correct glycosylation in vitro [23] and may represent new therapeutic options. Additionally, a company is currently developing a mannose-1-phoshate formulation using liposomes as the intravenous delivery system [11]. However, this will probably not cross the blood-brain barrier.

Very recently, results of the first clinical trial of acetazolamide in PMM2-CDG (AZATAX) were published [25]. The AZATAX study ( $N=24$ patients) was designed to establish whether acetazolamide, a drug that targets defective CaV2.1 channel activity, could be safely repurposed to treat cerebellar impairment in PMM2-CDG. The rationale was that disrupted $\mathrm{N}$-glycosylation of CaV2.1 contributes to cerebellar syndrome in PMM2CDG [26], therefore symptoms could be improved upon administration of acetazolamide. Acetazolamide was well tolerated and the majority of patients showed a significant clinical improvement of their cerebellar syndrome [25]. Improvement in prothrombin time, factor $X$, and antithrombin was also documented [25].

\section{Abbreviations}

IEF: Isoelectric focusing; PMM2: Phosphomannomutase; PMM2-CDG: PMM2congenital disorder of glycosylation

\section{Acknowledgements \\ We are grateful to the patient's family for their constant cooperation and consent to publish this study.}

\section{Authors' contributions}

SCG was involved in patient treatment, planning and conduction of the treatment trial, drafted the manuscript and created the figures. TM was involved in planning and conduction of the treatment trial, responsible for the laboratory monitoring and critically revised the manuscript. EL performed genetic analysis, was involved in the treatment of the patient and critically revised the manuscript. HF, AS and US were involved in the treatment of the patient and critically revised the manuscript. CT was responsible for the enzymatic studies and critically revised the manuscript. MS was responsible for the preparation of the study drug and critically revised the manuscript. LH analyzed mutation phenotypes, drafted the Table and critically revised the manuscript. All authors read and approved the final manuscript.

\section{Funding}

Not applicable.

\section{Availability of data and materials} Not applicable.

\section{Ethics approval and consent to participate}

As this was a single patient experimental treatment trial in a palliative setting no ethic approval was required. The patients' parents gave their informed written consent for the treatment trial.

Consent for publication

The patients' parents gave their informed consent for the publication of this case report. 


\section{Competing interests}

The authors declare that they have no competing interests.

\section{Author details}

'Department of General Pediatrics, Adolescent Medicine and Neonatology, Faculty of Medicine, Medical Center - University of Freiburg, Mathildenstraße 1, 79106 Freiburg, Germany. ${ }^{2}$ Department of General Pediatrics, University Children's Hospital Münster, Münster, Germany. ${ }^{3}$ Center for Child and Adolescent Medicine, Department I, University of Heidelberg, 69120 Heidelberg, Germany. ${ }^{4}$ Pharmacy Department, Faculty of Medicine, Medical Center - University of Freiburg, Freiburg, Germany. ${ }^{5}$ Laboratory of Clinical Biochemistry and Metabolism, Department of General Pediatrics, Adolescent Medicine and Neonatology, Faculty of Medicine, Medical Center - University of Freiburg, Freiburg, Germany.

Received: 3 July 2019 Accepted: 24 September 2019

Published online: 22 October 2019

\section{References}

1. Sparks SE, Krasnewich DM. PMM2-CDG (CDG-la). In: Adam MP, Ardinger HH, Pagon RA, Wallace SE, Bean LJ, Stephens K, et al., editors. GeneReviews ${ }^{\circledast}$. Seattle: University of Washington, Seattle; 1993. http://www.ncbi.nIm.nih. gov/books/NBK1110/. Accessed 5 Feb 2019.

2. Chan B, Clasquin M, Smolen GA, Histen G, Powe J, Chen Y, et al. A mouse model of a human congenital disorder of glycosylation caused by loss of PMM2. Hum Mol Genet. 2016:25:2182-93.

3. Panneerselvam K, Etchison JR, Skovby F, Freeze HH. Abnormal metabolism of mannose in families with carbohydrate-deficient glycoprotein syndrome type 1. Biochem Mol Med. 1997;61:161-7.

4. Panneerselvam K, Freeze HH. Mannose corrects altered N-glycosylation in carbohydrate-deficient glycoprotein syndrome fibroblasts. J Clin Invest. 1996;97:1478-87.

5. Rush JS, Panneerselvam K, Waechter CJ, Freeze HH. Mannose supplementation corrects GDP-mannose deficiency in cultured fibroblasts from some patients with Congenital Disorders of Glycosylation (CDG). Glycobiology. 2000;10:829-35

6. Körner C, Lehle L, von Figura K. Carbohydrate-deficient glycoprotein syndrome type 1: correction of the glycosylation defect by deprivation of glucose or supplementation of mannose. Glycoconj J. 1998;15:499-505.

7. Schneider A, Thiel C, Rindermann J, DeRossi C, Popovici D, Hoffmann GF, et al. Successful prenatal mannose treatment for congenital disorder of glycosylation-la in mice. Nat Med. 2011;18:71-3.

8. Kjaergaard S, Kristiansson B, Stibler H, Freeze HH, Schwartz M, Martinsson T, et al. Failure of short-term mannose therapy of patients with carbohydratedeficient glycoprotein syndrome type 1A. Acta Paediatr. 1998;87:884-8.

9. Mayatepek E, Kohlmüller D. Mannose supplementation in carbohydratedeficient glycoprotein syndrome type I and phosphomannomutase deficiency. Eur J Pediatr. 1998:157:605-6.

10. Mayatepek $E$, Schröder M, Kohlmüller D, Bieger WP, Nützenadel W. Continuous mannose infusion in carbohydrate-deficient glycoprotein syndrome type I. Acta Paediatr. 1997;86:1138-40.

11. Brasil S, Pascoal C, Francisco R, Marques-da-Silva D, Andreotti G, Videira PA et al. CDG therapies: from bench to bedside. Int J Mol Sci. 2018;19(5) pii: E1304

12. Niehues R, Hasilik M, Alton G, Körner C, Schiebe-Sukumar M, Koch HG, et al. Carbohydrate-deficient glycoprotein syndrome type Ib. Phosphomannose isomerase deficiency and mannose therapy. J Clin Invest. 1998;101:1414-20.

13. Grünewald S, Schollen E, Van Schaftingen E, Jaeken J, Matthijs G. High residual activity of PMM2 in patients' fibroblasts: possible pitfall in the diagnosis of CDG-la (phosphomannomutase deficiency). Am J Hum Genet. 2001;68:347-54.

14. Le Bizec C, Vuillaumier-Barrot S, Barnier A, Dupré T, Durand G, Seta N. A new insight into PMM2 mutations in the French population. Hum Mutat 2005:25:504-5.

15. Pirard M, Matthijs G, Heykants L, Schollen E, Grünewald S, Jaeken J, et al. Effect of mutations found in carbohydrate-deficient glycoprotein syndrome type IA on the activity of phosphomannomutase 2. FEBS Lett. 1999;452:319-22.

16. Silvaggi NR, Zhang C, Lu Z, Dai J, Dunaway-Mariano D, Allen KN. The X-ray crystal structures of human alpha-phosphomannomutase 1 reveal the structural basis of congenital disorder of glycosylation type 1a. J Biol Chem. 2006;281:14918-26.
17. Alton G, Kjaergaard S, Etchison JR, Skovby F, Freeze HH. Oral ingestion of mannose elevates blood mannose levels: a first step toward a potential therapy for carbohydrate-deficient glycoprotein syndrome type I. Biochem Mol Med. 1997;60:127-33.

18. Hummel B, Hansen EC, Yoveva A, Aprile-Garcia F, Hussong R, Sawarkar R. The evolutionary capacitor HSP90 buffers the regulatory effects of mammalian endogenous retroviruses. Nat Struct Mol Biol. 2017;24:234-42.

19. Karras Gl, Yi S, Sahni N, Fischer M, Xie J, Vidal M, et al. HSP90 shapes the consequences of human genetic variation. Cell. 2017;168:856-66 e12.

20. Siegal ML. Molecular genetics: chaperone protein gets personal. Nature. 2017:545:36-7.

21. Andreotti G, Cabeza de Vaca I, Poziello A, Monti MC, Guallar V, Cubellis MV. Conformational response to ligand binding in phosphomannomutase2: insights into inborn glycosylation disorder. J Biol Chem. 2014;289:34900-10.

22. Thiesler CT, Cajic S, Hoffmann D, Thiel C, van Diepen L, Hennig R, et al. Glycomic characterization of induced pluripotent stem cells derived from a patient suffering from phosphomannomutase 2 congenital disorder of glycosylation (PMM2-CDG). Mol Cell Proteomics. 2016;15:1435-52.

23. Eklund EA, Merbouh N, Ichikawa M, Nishikawa A, Clima JM, Dorman JA, et al. Hydrophobic Man-1-P derivatives correct abnormal glycosylation in type I congenital disorder of glycosylation fibroblasts. Glycobiology. 2005;15: 1084-93.

24. Hardré R, Khaled A, Willemetz A, Dupré T, Moore S, Gravier-Pelletier C, et al. Mono, di and tri-mannopyranosyl phosphates as mannose-1phosphate prodrugs for potential CDG-la therapy. Bioorg Med Chem Lett. 2007:17:152-5.

25. Martínez-Monseny AF, Bolasell M, Callejón-Póo L, Cuadras D, Freniche V, Itzep DC, et al. AZATAX: acetazolamide safety and efficacy in cerebellar syndrome in PMM2 congenital disorder of glycosylation (PMM2-CDG). Ann Neurol. 2019:85:740-51.

26. Izquierdo-Serra M, Martínez-Monseny AF, López L, Carrillo-García J, Edo A, Ortigoza-Escobar JD, et al. Stroke-like episodes and cerebellar syndrome in phosphomannomutase deficiency (PMM2-CDG): evidence for hypoglycosylation-driven channelopathy. Int J Mol Sci. 2018;19(2) pii: E619.

\section{Publisher's Note}

Springer Nature remains neutral with regard to jurisdictional claims in published maps and institutional affiliations.

Ready to submit your research? Choose BMC and benefit from:

- fast, convenient online submission

- thorough peer review by experienced researchers in your field

- rapid publication on acceptance

- support for research data, including large and complex data types

- gold Open Access which fosters wider collaboration and increased citations

- maximum visibility for your research: over $100 \mathrm{M}$ website views per year

At BMC, research is always in progress.

Learn more biomedcentral.com/submission 